\title{
Adipose Tssue Expression of Gelatinases in Mouse Models of Obesity
}

\author{
H. R. Lijnen ${ }^{1}$, E. Maquoi ${ }^{1}$, P. Holvoet ${ }^{1}$, A. Mertens ${ }^{1}$, F. Lupu², P. Morange ${ }^{3}$, M. C. Alessi3 ${ }^{3}$ \\ I. J uhan-Vague ${ }^{3}$
}

${ }^{1}$ C enter for Molecular and Va scular Biology, University of Leuven, Leuven, Belgium;

2Vasc ular Biology La boratory, Thrombosis Research Institute, Lond on, UK; 3Ha ema tology Laboratory, CHU Timone, Marseille, France

\section{Key words}

Obesity, matrix metalloproteinases, gelatinase

\section{Summary}

Following the observation by Brown et al. (Am J Physiol 1997; 272: C937-49) that primary rat adipocytes in culture secrete gelatinase A (MMP-2), we have evaluated gelatinase expression in adipose tissue with the use of mouse models of obesity. Wild-type mice were kept on a standard fat diet (SFD) or on a high fat diet (42\% fat, HFD) and genetically obese $\mathrm{db} / \mathrm{db}$ mice were kept on SFD; gonadal and subcutaneous fat pads were removed and analysed ex vivo. These studies revealed that: 1) the HFD induced adipocyte hypertrophy; 2) after 32 weeks, significantly higher levels of $70 \mathrm{kDa}(\mathrm{p}<0.05)$ and $65 \mathrm{kDa}$ proMMP-2 ( $p<0.01)$ were observed in extracts of gonadal fat pads of mice on HFD; 3) the contribution of active MMP-2 to the total level was comparable in SFD and HFD groups (20 to 30\%); and 4) gelatinase B (MMP-9) was not consistently detected. These findings were confirmed by gelatin zymography and by mRNA determination using competitive RT-PCR. The presence of MMP-2 in the adipose tissue was confirmed immunologically and its localization in adipocytes revealed by immunogold electron microscopy. The potential functional role of MMP-2 in adipose tissue remains to be determined.

\section{Introduction}

Obestiy is a common disorder, and its related diseases such as noninsulin-dependent diabetes mellitus, atherosclerosis and hypertension are a major cause of death and disability in Western societies. Development of obesity is associated with extensive modifications in adipose tissue involving angiogenesis and extracellular matrix (ECM) proteolysis (1). Proteolytic systems, e.g. the plasminogen/plasmin and matrix metalloproteinase (MMP) system, contribute to tissue remodelling by degradation of ECM and basement membrane components or activation of latent growth factors $(2,3)$. It is well known that plasminogen activator inhibitor-1 (PAI-1), the main physiological plasminogen activator inhibitor, is highly expressed in adipose tissue (4-8). The mechanism by which it affects adipose tissue growth or metabolism as shown by studies in gene-deficient mice (8) is, however, not resolved.

Correspondence to: H.R. Lijnen, Center for Molecular and Vascular Biology, University of Leuven, Campus Gasthuisberg, O \& N, Herestraat 49, B-3000 Leuven, Belgium - Tel.: 32-16-345775; Fax: 32-16-345990; E-mail: roger.lijnen@med.kuleuven.ac.be
Little is known, also, on a potential role of MMP system components in adipose tissue development.

Gelatinases (type IV collagenases) are a class of MMPs which degrade basement membrane collagen and gelatin. As other MMPs, they are secreted in a latent (proMMP) form that can be activated extracellularly via different mechanisms. Activation of proMMP-9 (progelatinase B) can be achieved by plasmin, whereas direct activation of proMMP-2 (progelatinase A) appears to occur via plasmin-independent mechanisms (9). Brown et al. (10) reported that primary rat adipocytes cultured in basement membrane component gels migrate and organize into large multicellular clusters. This process involves initial remodeling and eventually destruction of the ECM. Adipocyte conditioned medium was found to contain a MMP-2 like gelatinolytic activity, that was suggested to play a role in the formation of multicellular clusters (10).

In the present study we document high expression of gelatinase A (MMP-2) in adipose tissue with the use of mouse models of obesity.

\section{Materials and Methods}

\section{Experimental Protocol}

Age (5 weeks) and sex-matched wild-type mice ( $\mathrm{n}=6$ each) (mixed $75 \%$ C57/B16: 25\% 129SVj genetic background) were kept on a normal standard chow (4\% fat, SFD) or were given a high-fat diet (42\% fat, HFD; Harlan TD 88137, Zeist, The Netherlands) for 17 or 32 weeks. In addition, db/db mice and their lean counterparts $(n=4)(C 57 / B 16$ background $)$, obtained by crossing heterozygotes (Jackson Laboratory, Bar Harbor, ME) were kept on SFD for 34 to 43 weeks. Following overnight fasting, the mice were anesthetized by intraperitoneal injection of $60 \mathrm{mg} / \mathrm{kg}$ Nembutal (Abbott Laboratories, North Chicago, IL). Blood was collected with or without addition of trisodium citrate (final concentration $0.01 \mathrm{M})$. Gonadal $(\mathrm{GON})$, retroperitoneal (RP) and subcutaneous (SC) fat pads were removed, weighed, and immediately frozen. All animal experiments were approved by the local ethical committee and were performed in accordance with the guiding principles of the American Physiological Society and the International Society on Thrombosis and Haemostasis.

\section{Assays}

The mean size of adipocytes was determined on $15 \mu \mathrm{m}$ frozen-cut adipose tissue sections, stained with haematoxylin under standard conditions. Therefore, the cell areas of at least 200 sections were measured using a computerized image analyzer (Samba 2005 TITN - Alcatel, France), and the volume of each cell was calculated assuming spherical morphology (11). Lipid extraction was performed according to Folch et al. (12). The number of adipocytes in the tissue was calculated as the ratio of the lipid weight in the total fat pad over the mean adipocyte lipid content (mean volume $\times$ lipid density), assuming that the volume of the adipocyte corresponds to the triglyceride content (13). 
Zymographic analysis of gelatinases was performed on $10 \%$ Tris-glycine gels with $0.1 \%$ gelatin (14). The lysis of the substrate gel (area $X$ intensity) was quantitated using the Quantimed 600 image analysis software (Leica, Cambridge, $\mathrm{UK}$ ) and expressed in arbitrary units (AU) of lysis per mg total protein in adipose tissue extracts $(15,16)$.

Extraction of adipose tissue (about $1 \mathrm{~g} / \mathrm{ml}$ ) was performed by overnight incubation at $4^{\circ} \mathrm{C}$ on a tilting table in $10 \mathrm{mM}$ sodium phosphate buffer, $\mathrm{pH} 7.2$, containing $150 \mathrm{mM} \mathrm{NaCl}, 1 \%$ Triton X-100, $0.1 \%$ SDS, $0.5 \%$ sodium deoxycholate and $0.2 \% \mathrm{NaN}_{3}$. After centrifugation, the protein concentration of the supernatant was determined (BCA assay, Pierce). Immunoprecipitation with anti-MMP-2 or anti-MMP-9 antisera was performed as described (16). Mature adipocytes and stromal-vascular cells were derived from adipose tissue by treatment with collagenase as described (5), and kept for up to $72 \mathrm{~h}$ in Dulbecco's MoD Eagle Medium, with sodium pyruvate, glucose and pyridoxine (GibcoBRL), containing 2\% BSA, $100 \mathrm{IU} / \mathrm{ml}$ penicillin-streptomycin.

Total RNA was extracted from adipose tissue and from isolated stromalvascular cells and mature adipocytes by the HighPure RNA tissue and HighPure RNA isolation kits (Roche), respectively, and RNA concentrations were measured by the RiboGreen RNA quantification kit (Molecular Probes Europe).
MMP-2 mRNA and 28S rRNA levels in total RNA were measured by competitive RT-PCR as follows. Aliquots (10 ng) of total DNA-free RNA were mixed with serial dilutions of a synthetized competitor RNA (pCTR01, ranging from $8 \times 10^{4}$ copies to 1250 copies/tube and $1 \times 10^{7}$ copies to $37 \times 10^{4}$ copies/tube, for MMP-2 and 28S, respectively). The RNA mixtures were subjected to RT-PCR using the GeneAmp Thermostable RNA PCR Kit (Perkin Elmer) and two pairs of oligonucleotides (Gibco BRL): 5' - G G C T G G T C A G T G G C T T G G G G T A -3' and 5' - A G A T C T T C T T C T T C A A G G A C C G G T T - 3' for MMP-2 and 5' - G T T C A C C C A C T A A T A G G G A A C G T G A - 3' and 5' - G G A T T C T G A C T T A G A G G $\mathrm{C} \mathrm{G} \mathrm{T} \mathrm{T} \mathrm{-} \mathrm{3'} \mathrm{for} \mathrm{28S.} \mathrm{Reverse} \mathrm{transcription} \mathrm{was} \mathrm{performed} \mathrm{at} 70^{\circ} \mathrm{C}$ for $15 \mathrm{~min}$ followed by $2 \mathrm{~min}$ incubation at $95^{\circ} \mathrm{C}$ for denaturation of RNA-DNA heteroduplexes. Amplification started by $15 \mathrm{~s}$ at $94^{\circ} \mathrm{C}, 20 \mathrm{~s}$ at $68^{\circ} \mathrm{C}$ and $10 \mathrm{~s}$ at $72^{\circ} \mathrm{C}$ ( 32 cycles for MMP-2 and 19 cycles for $28 \mathrm{~S}$ ) and terminated by $2 \mathrm{~min}$ at $72^{\circ} \mathrm{C}$ on a GeneAmp PCR System 9700 thermocycler (Perkin Elmer). RT-PCR products were run on $10 \%$ acrylamide gels and stained with SYBR Green (Molecular Probes Europe). The expected size for MMP-2 is $271 \mathrm{bp}$ for the pCTR01 and $225 \mathrm{bp}$ for the endogenous mRNA, and for $28 \mathrm{~S}$ the expected size is $269 \mathrm{bp}$ for the pCTR01 and $212 \mathrm{bp}$ for the endogenous rRNA. The intensity

\begin{tabular}{|c|c|c|c|c|c|c|}
\hline \multirow[b]{2}{*}{ Parameter } & \multicolumn{3}{|c|}{ SFD } & \multicolumn{3}{|c|}{ HFD } \\
\hline & SC & GON & $\mathrm{RP}$ & SC & GON & $\mathrm{RP}$ \\
\hline Weight (g) & $0.25 \pm 0.06$ & $0.34 \pm 0.09$ & $0.12 \pm 0.03$ & $2.7 \pm 0.31 *$ & $2.3 \pm 0.43 *$ & $0.79 \pm 0.07 *$ \\
\hline Protein extracted ${ }^{(a)}(\mathrm{mg} / \mathrm{g})$ & $15 \pm 1.4$ & $11 \pm 0.78$ & $10 \pm 2.8$ & $8.2 \pm 0.86^{*}$ & $6.4 \pm 0.52 *$ & $5.2 \pm 0.44$ \\
\hline $70 \mathrm{kDa}$ proMMP- $2^{(\mathrm{b})}$ & $39 \pm 4$ & $35 \pm 19$ & ND & $52 \pm 9$ & $51 \pm 29$ & ND \\
\hline $65 \mathrm{kDa}$ proMMP- $2^{(\mathrm{b})}$ & $108 \pm 18$ & $159 \pm 28$ & $45 \pm 9$ & $117 \pm 39$ & $134 \pm 17$ & $65 \pm 17$ \\
\hline $58 \mathrm{kDa}$ MMP- $2^{(\mathrm{b})}$ & $43 \pm 11$ & $52 \pm 23$ & $19 \pm 8$ & $78 \pm 23$ & $30 \pm 13$ & $21 \pm 6$ \\
\hline
\end{tabular}

Data are mean \pm SEM of 6 to 11 determinations. *, $\mathrm{p}<0.005$ versus SFD; N.D., not detectable;

(a) , amount of protein extracted per $\mathrm{g}$ tissue; ${ }^{\left({ }^{b}\right)}$, gelatinase levels, expressed in arbitrary units of lysis per mg protein in the extracts. SC, subcutaneous fat pad; GON, gonadal fat pad; RP, retroperitoneal fat pad.

\begin{tabular}{|c|c|c|c|c|c|c|}
\hline \multirow[b]{2}{*}{ Parameter } & \multicolumn{3}{|c|}{ lean } & \multicolumn{3}{|c|}{$\mathrm{db} / \mathrm{db}$} \\
\hline & $\mathrm{SC}$ & GON & $\mathrm{RP}$ & SC & GON & $\mathrm{RP}$ \\
\hline Weight $(\mathrm{g})$ & $0.30 \pm 0.05$ & $0.40 \pm 0.04$ & $0.19 \pm 0.02$ & $9.1 \pm 2.0^{*}$ & $2.5 \pm 1.0^{*}$ & $1.9 \pm 0.42 *$ \\
\hline Protein extracted $^{(a)}(\mathrm{mg} / \mathrm{g})$ & $16 \pm 0.93$ & $13 \pm 1.5$ & $12 \pm 1.4$ & $11 \pm 1.5$ & $12 \pm 1.2$ & $13 \pm 1.9$ \\
\hline $70 \mathrm{kDa}$ proMMP- $2^{(\mathrm{b})}$ & $36(1 / 4)$ & $96 \pm 3(2 / 4)$ & - & $20 \pm 1.2$ & $64 \pm 11$ & $15 \pm 3$ \\
\hline $65 \mathrm{kDa}$ proMMP- $2^{(\mathrm{b})}$ & $178 \pm 22$ & $124 \pm 33$ & - & $144 \pm 12$ & $217 \pm 16$ & $121 \pm 23$ \\
\hline $61 \mathrm{kDa} M M P-2^{(b)}$ & $68 \pm 5$ & N.D. & - & $60 \pm 4$ & $42 \pm 14(2 / 4)$ & $38 \pm 4$ \\
\hline $58 \mathrm{kDa} M M P-2^{(b)}$ & $39 \pm 8$ & $9 \pm 8(2 / 3)$ & - & $2 \pm 1$ & $33 \pm 4$ & $2.1 \pm 0.9(3 / 4)$ \\
\hline
\end{tabular}

Data are mean $\pm S E M$ of 4 determinations; the numbers in parenthesis indicate the number of samples

with detectable levels. *, p< 0.05 versus lean mice; N.D., not detectable.

(a) amount of protein extracted per $\mathrm{g}$ tissue; ${ }^{(b)}$ gelatinase levels expressed in arbitrary units of lysis per mg protein in the extracts. SC, subcutaneous fat pad; GON, gonadal fat pad; RP, retroperitoneal fat
Table 1 Gelatinase levels in extracts of adipose tissue of wild-type mice after 17 weeks of SFD or HFD

Table 2 Gelatinase levels in extracts of adipose tissue of $\mathrm{db} / \mathrm{db}$ mice and their lean counterparts

pad. 
of the bands corresponding to competitor and endogenous RNAs was quantified with a Fluor-S Multilmager System (Bio-Rad) using the Multi-Analyst software. The logarithm of the band intensity ratio of competitor product to the endogenous product was plotted as a function of the logarithm of the initial copy numbers of competitor added. Initial copy numbers of endogenous MMP-2 mRNA and 28S rRNA in the samples were calculated by linear regression analysis of the plots, as described by Nie et al. (17). In order to normalize the MMP-2 mRNA levels in the different samples, the calculated number of copies of endogenous MMP- 2 mRNA was divided by the calculated number of copies of endogenous $28 \mathrm{~S}$ rRNA.

Immunostaining with specific antisera against murine MMP-2 and MMP-9 was performed on $15 \mu \mathrm{m}$ sections, as described elsewhere $(16,18)$. Immunogold electron microscopy with MMP-2 antiserum was performed as described previously (18).

Blood glucose concentrations were measured using Glucocard strips (Menarini Diagnostics). For glucose tolerance tests, glucose ( $2 \mathrm{mg} / \mathrm{g}$ body weight) was injected intraperitoneally and glucose levels were measured at different time points (0-120 min) after injection. White blood cells, red blood cells, platelets, haemoglobin and hematocrit were determined using standard laboratory assays. PAI-1 levels were measured with a specific ELISA (19). Statistical analysis was performed by non-parametric t-test.

\section{Results}

\section{Blood and Adipose Tissue Parameters}

Wild-type mice on HFD had a higher body weight after 17 weeks than their littermates kept on SFD $(39 \pm 3.1 \mathrm{~g}$ versus $27 \pm 2.2 \mathrm{~g}$; $\mathrm{p}=$ $0.03)$; after 32 weeks on HFD or SFD, these body weights did not increase further $(39 \pm 2.2 \mathrm{~g}$ versus $26 \pm 2.8 \mathrm{~g} ; \mathrm{p}<0.01)$. At 17 weeks, the mean diameter of adipocytes in the gonadal deposit was significantly higher on HFD than on SFD $(80 \pm 5.3 \mu \mathrm{m}$ versus $49 \pm 4.2 \mu \mathrm{m}$; $\mathrm{p}=0.001$ ), whereas the number of adipocytes was not significantly different $\left(6.1 \pm 0.93 \times 10^{6}\right.$ versus $\left.5.1 \pm 1.2 \times 10^{6} ; \mathrm{p}=0.57\right)$. At 32 weeks, no further increase in mean diameter of adipocytes was observed on HFD $(86 \pm 1.6 \mu \mathrm{m})$. At 17 weeks, glucose levels were significantly higher for mice on HFD $(102 \pm 12$ versus $70 \pm 2.6 \mathrm{mg} / \mathrm{dl}$; $\mathrm{p}<0.005)$. Glucose tolerance tests indicated significantly higher ( $p<0.05$ ) blood glucose levels at 45 to $120 \mathrm{~min}$ after intraperitoneal glucose injection in mice on HFD as compared to SFD (data not shown). Plasma PAI-1 antigen levels after 17 or 32 weeks on HFD were significantly enhanced as compared to SFD $(5.6 \pm 0.73 \mathrm{ng} / \mathrm{ml}$ versus $2.5 \pm 0.28 \mathrm{ng} / \mathrm{ml}$ at 17 weeks, $\mathrm{p}<0.01$; and $6.8 \pm 1.3 \mathrm{ng} / \mathrm{ml}$ versus $1.4 \pm 0.14 \mathrm{ng} / \mathrm{ml}$ at 32 weeks, $\mathrm{p}<0.005)$. Other haemostatic parameters including white and red blood cell and platelet counts, haemoglobin and haematocrit were not different (not shown). The adipose tissue weight in the 3 different territories was significantly higher in mice on HFD then on SFD (Table 1). For the gonadal fat deposits similar data were obtained for males and females $(2.6 \pm 0.42 \mathrm{~g}$ and $2.1 \pm 0.63 \mathrm{~g}$; $\mathrm{p}=0.53$ ), and were therefore also pooled. PAI-1 antigen levels in adipose tissue extracts at 17 weeks were not significantly different between HFD and SFD groups $(4.6 \pm 1.3 \mathrm{ng} / \mathrm{mg}$ protein in the extract versus $1.1 \pm 0.48 \mathrm{ng} / \mathrm{mg}$ for SC tissue, $4.5 \pm 0.75$ versus $2.5 \pm 0.74$ $\mathrm{ng} / \mathrm{mg}$ for GON tissue, and $7.8 \pm 2.6$ versus $4.6 \pm 1.6 \mathrm{ng} / \mathrm{mg}$ for RP tissue) (mean \pm SEM of 4 to 6 determinations).

$\mathrm{Db} / \mathrm{db}$ mice kept on SFD had a significantly higher body weight then their lean counterparts $(65 \pm 9.3 \mathrm{~g}$ for $\mathrm{db} / \mathrm{db}$ mice at 34 weeks, versus $25 \pm 0.23 \mathrm{~g}$ for lean mice at 43 weeks; mean \pm SEM, $\mathrm{p}=0.029$ ), and the adipose tissue weight in the 3 territories was significantly higher (Table 2). PAI-1 antigen levels in adipose tissue extracts of $\mathrm{db} / \mathrm{db}$ mice were significantly higher than those of their lean littermates $(8.7 \pm 2.7$ versus $0.56 \pm 0.03 \mathrm{ng} / \mathrm{mg}$ for SC tissue, $10 \pm 3.5$ versus $0.58 \pm 0.06 \mathrm{ng} / \mathrm{mg}$

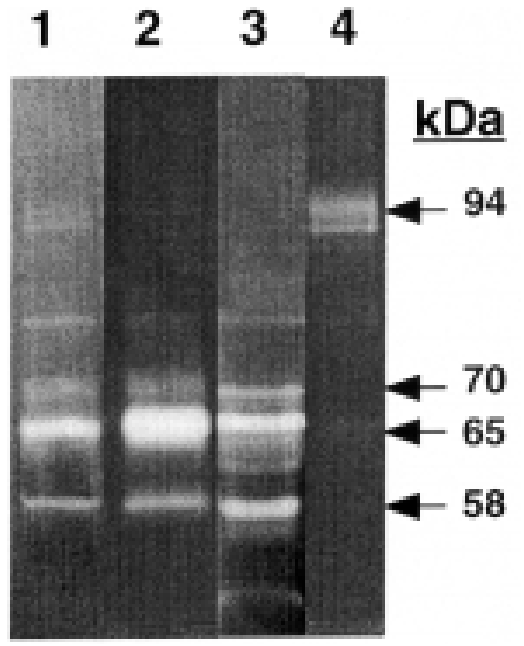

Fig. 1 Zymographic analysis on gelatin-containing gels of extracts of adipose tissue ( $20 \mu \mathrm{g}$ total protein) of mice kept on HFD (lane 1); lanes 2 and 3 show the eluates of immunoadsorption with anti-MMP-2 antiserum of extracts from adipose tissue and of serum-free culture medium of isolated adipocytes, lane 4 shows the eluate of immunoadsorption with anti-MMP-9 antiserum of extracts from adipose tissue of mice on HFD

for GON tissue, and $8.5 \pm 2.8$ versus $0.74 \pm 0.14 \mathrm{ng} / \mathrm{mg}$ for RP tissue) (mean \pm SEM; $n=4$ or 5 ; all $\mathrm{p}<0.05$ ).

\section{Gelatinase Expression}

After 17 weeks on SFD or HFD, mainly $70 \mathrm{kDa}$ and $65 \mathrm{kDa}$ pro MMP-2 and $58 \mathrm{kDa}$ active MMP-2 levels were detected in adipose tissue extracts of wild-type mice (Table 1), whereas $61 \mathrm{kDa}$ MMP-2 was not consistently detected (Fig. 1). The identity of MMP-2 was confirmed by immunoprecipitation with a specific antiserum (Fig. 1, lane 2). MMP-2 levels, expressed as arbitrary units of lysis per mg protein in the extracts, were not significantly different between SFD or HFD groups (Table 1). 94 kDa proMMP-9 was only detected at low concentration in some samples, although its presence could be confirmed by immunoprecipitation (Fig. 1, lane 4). Most levels were, however, below the detection limit of the assay.

After 32 weeks the weight of the different fat pads was also significantly higher ( $p<0.05$ ) on HFD than on SFD, but they were not different from those at 17 weeks $(0.35 \pm 0.14 \mathrm{~g}, 0.55 \pm 0.23 \mathrm{~g}$ and $0.18 \pm$ $0.11 \mathrm{~g}$ for SC, GON and RP tissue on SFD, with corresponding values of $1.8 \pm 0.36 \mathrm{~g}, 2.4 \pm 0.58 \mathrm{~g}$ and $0.94 \pm 0.21 \mathrm{~g}$ on HFD). The amounts of protein extracted per $g$ tissue and the PAI-1 antigen levels were also comparable (not shown). Again, mainly $70 \mathrm{kDa}$ and $65 \mathrm{kDa}$ proMMP2 and $58 \mathrm{kDa}$ MMP-2 were detected. The levels were not significantly different for SFD and HFD (data not shown), with the exception of higher levels of $70 \mathrm{kDa}$ proMMP-2 in GON fat pads of mice on HFD $(53 \pm 14$ versus $7.0 \pm 1.6 \mathrm{AU} / \mathrm{mg}, \mathrm{p}<0.05)$ and of $65 \mathrm{kDa}$ proMMP-2 in GON (260 \pm 43 versus $62 \pm 16 \mathrm{AU} / \mathrm{mg}, \mathrm{p}<0.01)$ and RP $(260 \pm 49$ versus $70 \pm 38 \mathrm{AU} / \mathrm{mg}, \mathrm{p}<0.05$ ) fat pads of mice on HFD. (pro)MMP9 was not consistently detected in SFD samples (in only 2 out of 5 or 6 ), and appeared somewhat more abundant in HFD samples (in 3 or 4 out of 5 for the different fat pad territories). Levels of $94 \mathrm{kDa}$ proMMP-2 were, however, low and ranged between $9.9 \pm 2.6$ and $34 \pm 16 \mathrm{AU}$ of lysis per mg protein in the different groups (data not shown).

Immunostaining with an antiserum specific for murine MMP-2 confirmed its presence in adipose tissue sections of mice on SFD and HFD 

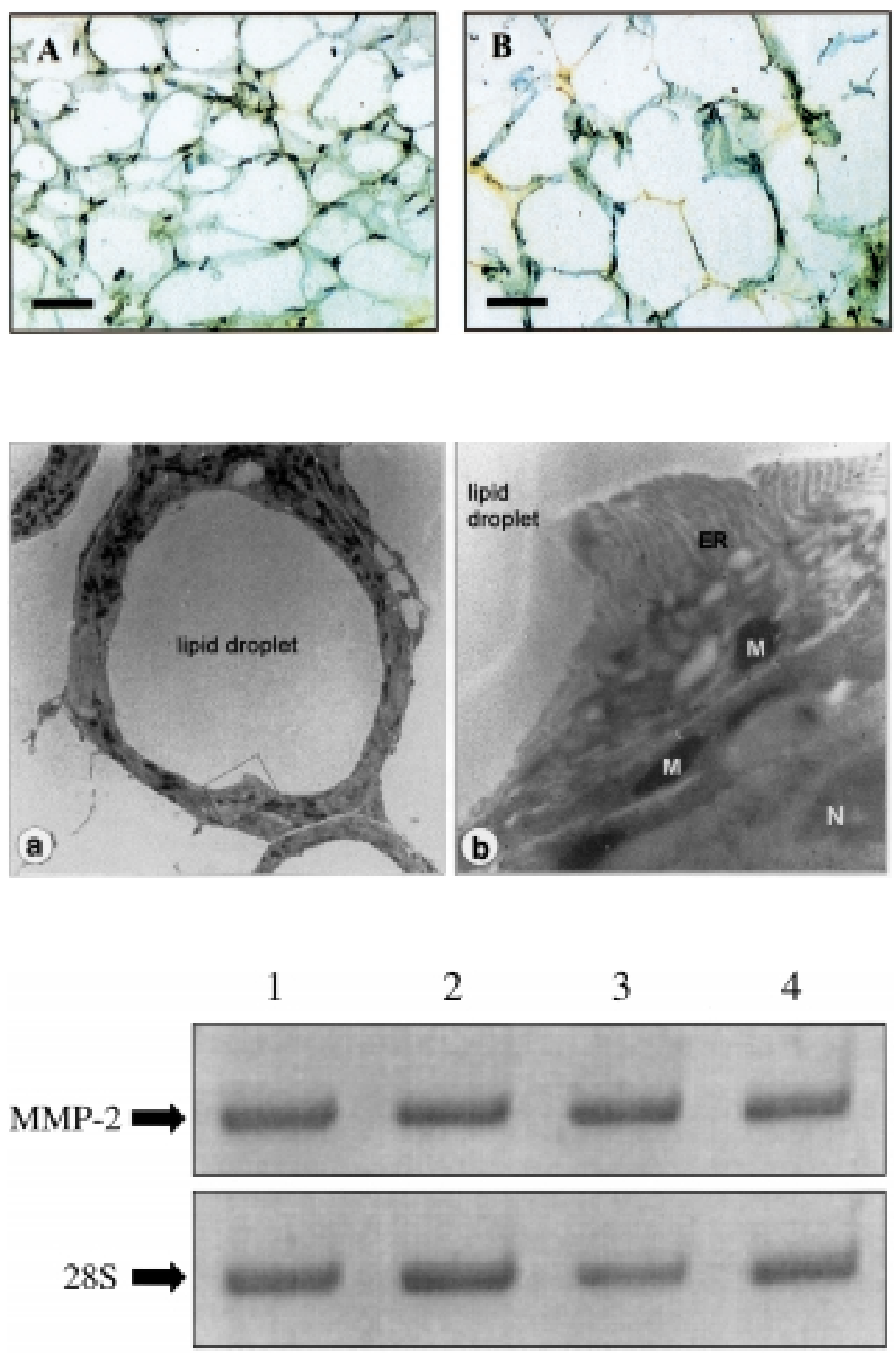

Fig. 2 Immunostaining with antiserum against MMP-2 of adipose tissue sections taken from mice on SFD (panel A) or HFD (panel B)

Fig. 3 Ultrastructural localization by immunogold electron microscopy of MMP-2 in gonadal adipose tissue of a mouse on HFD.

(a) Low magnification electron micrograph of paraformaldehyde fixed, Lowicryl embedded adipose tissue, showing a mature adipocyte.

(b) High magnification of the cytoplasmic area (rectangle in panel a), revealing the presence of MMP-2 labeled gold particles in the endoplasmic reticulum (ER). In the lower right corner part of the nucleus (N) can be recognized, and the perinuclear cytoplasm is rich in mitochondria $(\mathrm{M})$ that appear as dark elongated bodies

Fig. 4 mRNA determination in subcutaneous adipose tissue from wild-type mice on SFD (lane 1) or HFD (lane 2), and in isolated adipocytes (lane 3) or stromal-vascular cells (lane 4) from subcutaneous adipose tissue of wild-type mice on SFD

(Fig. 2). Immunogold electron microscopy showed the localisation of MMP-2 in mature adipocytes (Fig. 3). Fig. 4a shows a mature adipocyte, characterized by a single large lipid inclusion (lipid droplet) which occupies the central part of the cytoplasma, whereas Fig. 3b at higher magnification reveals the presence of MMP-2 labeled gold particles in the area of the endoplasmic reticulum.

Quantitation of MMP-2 mRNA levels by competitive RT-PCR revealed comparable levels in SC fat pads of wild-type mice after 17 weeks on HFD as compared to SFD (ratio MMP-2 mRNA/28S rRNA, $\times 10^{-3}$ ): $2.1 \pm 1.4$ versus $3.9 \pm 2.7$ (mean \pm SEM). In GON fat pads of mice kept on HFD, MMP-2 mRNA levels were also similar $(3.4 \pm 1.5)$. The presence of MMP-2 mRNA was confirmed in isolated mature adipocytes at a comparable level than in stromal-vascular cells derived from subcutaneous adipose tissue of wild-type mice kept on SFD (ratio MMP-2 mRNA/28S rRNA, $\times 10^{-3}$ ): 18 versus 21 (Fig. 4). In agreement with these findings, MMP-2 antigen was confirmed by immunoprecipitation on serum-free culture medium of isolated adipocytes (Fig. 1, lane 3). Quantitation of MMP-9 mRNA revealed only very low expression in the different samples $(<20$ copies per ng total RNA) (data not shown).

In adipose tissue extracts obtained from $\mathrm{db} / \mathrm{db}$ mice and from their lean counterparts kept on SFD, $70 \mathrm{kDa}$ and $65 \mathrm{kDa}$ proMMP-2 and $58 \mathrm{kDa}$ MMP-2 were detected, whereas also the $61 \mathrm{kDa}$ MMP-2 species was more consistently present (Table 2). As also shown in Table 2, the $65 \mathrm{kDa}$ proMMP-2 form was the most abundant. With the wild-type mice, low $94 \mathrm{kDa}$ proMMP-9 levels were detected in the $\mathrm{SC}$ fat $(8.8 \pm 2.6 \mathrm{AU} / \mathrm{mg})$, whereas with the $\mathrm{db} / \mathrm{db}$ mice it was present in 2 out of $4 \mathrm{SC}$ samples ( 28 and $10 \mathrm{AU} / \mathrm{mg}$ ), in 4 of $4 \mathrm{GON}$ samples $(15 \pm 4.4 \mathrm{AU} / \mathrm{mg})$ and in 3 out of $4 \mathrm{RP}$ samples $(3.6 \pm 0.5 \mathrm{AU} / \mathrm{mg})$. No active MMP-9 was detected.

In GON and SC fat of db/db mice kept on SFD, MMP-2 mRNA levels were comparable to those observed in wild-type mice kept on 
HFD: ratios (MMP-2 mRNA/28S rRNA, $\times 10^{-3}$ ) of $3.2 \pm 2.1$ and $2.3 \pm$ 1.4 , respectively (mean \pm SEM; $n=4$ ). MMP-9 mRNA levels were very low ( $<20$ copies per ng total RNA).

\section{Disc ussion}

In vivo, adipocytes are organised into fat pads, vascularized and innervated structures resulting from the concerted assembly of adipose, vascular and nervous tissues (20). Formation of adipose tissue, the major cellular component of fat pads is a complex process requiring commitment of mesodermal stem cells to a preadipocyte lineage and differentiation of preadipocytes into adipocytes. These and other changes lead to rounding and formation of the intracellular lipid droplet, which lead to a cellular morphogenesis (10). Adipocytes secrete compounds that are involved in the control of blood flow and angiogenesis (21-24) and in the control of proliferation and differentiation of adipose precursor cells (25-28). Differentiation is also associated with an increase in the secretion of basement membrane components such as laminin, proteoglycans and type IV collagen (29). Differentiating adipocytes create cellular extensions, migrate from the stroma, form cellcell junctions and become organized into 3-dimensional multicellular structures, a process that is associated with migration through and remodeling of the original extracellular matrix (10). Cultured rat adipocytes were found to secrete gelatinase A (MMP-2) (10), a member of the matrix metalloproteinase (MMP) family that, as gelatinase B (MMP-9), degrades basement membrane collagen and gelatin. MMP-2 deficient mice were reported to have significantly lower body weight from birth on until adulthood, as compared to wild-type littermates (30). In these animals tumor-induced angiogenesis was also reduced (31). In the present study, we have monitored the expression and secretion of gelatinases in adipose tissue, obtained from mouse models of obesity.

Wild-type mice were kept on SFD or HFD for 17 weeks, resulting in a significantly higher body weight and adipose tissue (gonadal, subcutaneous and retroperitoneal) weight for the mice on HFD. As observed previously, this was associated with significantly higher blood glucose and plasma PAI-1 levels. Adipocyte hypertrophy appears to be the main mode of adipose tissue expansion in this model (8), as also reported previously in rats (32). In addition, genetically obese $\mathrm{db} / \mathrm{db}$ mice, lacking the leptin receptor, were used. Leptin is expressed and secreted by adipocytes in proportion to their triglyceride stores, and plasma levels correlate with the extent of obesity (33). Db/db mice, kept on SFD, had a significantly higher body and adipose tissue weight than their lean counterparts. Gelatinase expression in these models was monitored by measuring protein and mRNA levels in adipose tissue and isolated adipocytes.

In adipose tissue of wild-type mice kept on SFD or HFD for 17 weeks, mainly two proMMP-2 forms ( $70 \mathrm{kDa}$ and $65 \mathrm{kDa}$ ) and one active MMP-2 species ( $58 \mathrm{kDa}$ ) were detected by gelatin zymography. MMP-2 protein levels, expressed as arbitrary lysis units per mg protein in adipose tissue extracts, and MMP-2 mRNA levels, expressed as the ratio versus $28 \mathrm{~S}$ rRNA, were not significantly different between SFD and HFD groups. However, the total levels of the different molecular forms of MMP-2 in the adipose tissue of mice on HFD are much higher than in those on SFD: in SC fat pads the total amounts of $70 \mathrm{kDa}$ proMMP-2, $65 \mathrm{kDa}$ proMMP-2 and $58 \mathrm{kDa}$ MMP-2 are 8-fold, 6-fold and 11-fold higher, with corresponding values of 6-, 3- and 2-fold in GON fat pads. Total $65 \mathrm{kDa}$ proMMP- 2 and $58 \mathrm{kDa}$ MMP-2 levels are 5- or 4-fold higher in RP fat pads of mice on HFD. MMP-9 levels in contrast were low and were not consistently detected. After 32 weeks, similar data were obtained with the exception of higher levels of $70 \mathrm{kDa}$ and $65 \mathrm{kDa}$ proMMP-2 in GON fat pads of mice on HFD as compared to SFD; such difference was not observed at 17 weeks and remains unexplained.

Very similar results were obtained with adipose tissue obtained from $\mathrm{db} / \mathrm{db}$ mice on SFD; in contrast to wild-type mice, a $61 \mathrm{kDa}$ active MMP-2 species was more consistently detected, but the $65 \mathrm{kDa}$ pro MMP-2 was also the predominant molecular form. However, only 4 $\mathrm{db} / \mathrm{db}$ mice were studied in each group, thus precluding adequate statistical analysis. In both models, the contribution of active MMP-2 forms represents $15-30 \%$ of the total MMP-2 levels .

A similar pattern of MMP-2 expression was observed in culture medium of isolated adipocytes, and the localization of MMP-2 in mature adipocytes was further confirmed by immunogold electron microscopy on adipose tissue and mRNA determination on RNA isolated from adipocytes. In addition to isolated adipocytes, MMP-2 mRNA was also detected in the stromal-vascular cell fraction. Adipocytes represent between one-third and two-thirds of cells in adipose tissue, the remaining cells comprising the stromal-vascular fraction with blood and endothelial cells as well as adipocyte precursor cells (34). In our model, weight gain is accompanied by adipocyte hypertrophy without significant increase (about 20\%) in the number of adipocytes, but by an increase in the number of stroma cells. This may contribute to the apparent discrepancy between an only 1.5 -fold increase in adipocyte diameter and a 7-fold higher gonadal adipose tissue weight in the HFD group.

Thus, we have consistently detected high MMP-2 expression in adipose tissue in lean mice, in a diet-induced model of obesity as well as in genetically obese mice. MMP- 2 is detected in adipocytes, although this may not be the only source in the tissue. It is tempting to speculate that MMP-2 may play a role in the modulation of extracellular matrix and in angiogenesis during adipose tissue development. It remains to be investigated whether other components of the MMP system are expressed in the adipose tissue and whether modulation of the MMP system may affect obesity.

\section{Acknowledgements}

Skilful technical assistance by A. De Wolf, L. Frederix, G. Lemmens and B. Van Hoef is gratefully acknowledged. This study was supported by grants from the Flemish Fund for Scientific Research (FWO, contract G.0293.98) and from the IUAP (contract P4/34).

\section{References}

1. Crandall DL, Hausman GJ, Kral JG. A review of the microcirculation of adipose tissue: anatomic, metabolic, and angiogenic perspectives. Microcirculation 1997; 4: 211-32.

2. Dollery CM, McEwan JR, Henney AM. Matrix metalloproteinases and cardiovascular disease. Circ Res 1995; 77: 863-8.

3. Carmeliet P, Collen D. Development and disease in proteinase-deficient mice: role of the plasminogen, matrix metalloproteinase and coagulation system. Thromb Res 1998; 91: 255-85.

4. Samad F, Yamamoto K, Loskutoff DJ. Distribution and regulation of plasminogen activator inhibitor-1 in murine adipose tissue in vivo: induction by tumor necrosis factor- $\alpha$ and lipopolysaccharide. J Clin Invest 1996; 97: 37-46.

5. Alessi MC, Peiretti F, Morange P, Henry M, Nalbone G, Juhan-Vague I. Production of plasminogen activator inhibitor 1 by human adipose tissue. Possible link between viscaral fat accumulation and vascular disease. Diabetes 1997; 46: 860-7. 
6. Juhan-Vague I, Alessi MC. Regulation of fibrinolysis in the development of atherothrombosis: role of adipose tissue. Thromb Haemost 1999; 82: 832-6.

7. Samad F, Loskutoff DJ. Hemostatic gene expression and vascular disease in obesity: insights from studies of genetically obese mice. Thromb Haemost 1999; 82: 742-7.

8. Morange PE, Lijnen HR, Alessi MC, Kopp F, Collen D, Juhan-Vague I. Influence of PAI-1 on adipose tissue growth and on metabolic parameters in a murine model of diet-induced obesity. Arterioscler Thromb Vasc Biol 2000; 20: 1150-4.

9. Lijnen HR, Collen D. Matrix metalloproteinase system deficiencies and matrix degradation. Thromb Haemost 1999; 82: 837-45.

10. Brown LM, Fox HL, Hazen SA, LaNoue KF, Rannels SR, Lynch CJ. Role of the matrixin MMP-2 in multicellular organization of adipocytes cultured in basement membrane components. Am J Physiol 1997; 272: C937-C49.

11. Sjöström L, Bjöntorp P, Vrana J. Microscopic fat cell size measurements on frozen-cut adipose tissue in comparison with automatic determinations of osmium-fixed fat cells. J Lipid Res 1971; 12: 521-30.

12. Folch J, Lees M, Sloane Stanley GH. A simple method for the isolation and purification of total lipids from animal tissue. J Biol Chem 1957; 232: 497-508.

13. Gliemann J, Osterlind K, Vinten J, Gammeltoft S. A procedure for measurements of distribution spaces in isolated fat cells. Biochim Biophys Acta 1972; 286: 1-9.

14. Kleiner DE, Stetler Stevenson WG. Quantitative zymography: detection of picogram quantities of gelatinases. Anal Biochem 1994; 218: 325-9.

15. Lijnen HR, Van Hoef B, Lupu F, Moons L, Carmeliet P, Collen D. Function of plasminogen/plasmin and matrix metalloproteinase systems after vascular injury in mice with targeted inactivation of fibrinolytic system genes. Arterioscler Thromb Vasc Biol 1998; 18: 1035-45.

16. Lijnen HR, Silence J, Lemmens G, Frederix L, Collen D. Regulation of gelatinase activity in mice with targeted inactivation of components of the plasminogen/plasmin system. Thromb Haemost 1998; 79: 1171-6.

17. Nie GY, Wang J, Li Y, Salamonsen LA. Construction and application of a multispecific competitor to quantify mRNA of matrix metalloproteinases and their tissue inhibitors in small human biopsies. J Biochem Biophys Methods 1999; 40: 81-99.

18. Lijnen HR, Lupu F, Moons L, Carmeliet P, Goulding D, Collen D. Temporal and topographic matrix metalloproteinase expression after vascular injury in mice. Thromb Haemost 1999; 81: 799-807.

19. Declerck PJ, Verstreken M, Collen D. Immunoassay of murine t-PA, u-PA and PAI-1 using monoclonal antibodies raised in gene-inactivated mice. Thromb Haemost 1995; 74: 1305-9.

20. Flier JS. The adipocyte: storage depot or node on the energy information superhighway? Cell 1995; 80: 15-8.
21. Silverman KJ, Lund DP, Zetter BR, Lainey LL, Shahood JA, Freiman DG, Folkman J, Barger AC. Angiogenic activity of adipose tissue. Biochem Biophys Res Commun 1988; 153: 347-52.

22. Claffey KP, Wilkison WO, Spiegelman BM. Vascular endothelial growth factor; Regulation by cell differentiation and activated second messenger pathways. J Biol Chem 1992; 267: 16317-22.

23. Bouloumie A, Lafontan M, Busse R. Leptin, the product of Ob gene, promotes angiogenesis. Circ Res 1998; 83: 1059-66.

24. Darimont C, Saint-Marc P, Ailhaud G, Negrel R. Modulation of vascular tone and glycerol levels measured by in situ microdialysis in rat adipose tissue. Am J Physiol 1996; 271: E631-5.

25. Levine JA, Jensen MD, Eberhardt NL, O'Brien T. Adipocyte macrophage colony stimulating factor is a mediator of adipose tissue growth. J Clin Invest 1998; 101: 1557-64.

26. Negrel R, Gaillard D, Ailhaud G. Prostacyclin as a potent effector of adipose cell differentiation. Biochem J 1989; 257: 399-405.

27. Nougues J, Reyne Y, Barenton B, Chery T, Garandel V, Soriano J. Differentiation of adipocyte precursors in a serum-free medium is influenced by glucocorticoids and endogenously produced insulin-like growth factor-I. Int J Obes 1993; 17: 159-67.

28. Rahimi N, Tremblay E, MacAdam L, Roberts A, Elliot B. Autocrine secretion of TGF-beta1 and TGF-beta2 by preadipocytes and adipocytes: a potent negative regulator of adipocyte differentiation and proliferation of mammary carcinoma cells. In Vitro Cell Dev Biol Anim 1998; 34: 412-20.

29. Nakajima I, Yamaguchi T, Ozutsumi K, Aso H. Adipose tissue extracellular matrix: newly organized by adipocytes during differentiation. Differentiation 1998; 63: 193-200.

30. Itoh T, Ikeda T, Gomi H, Nakao S, Suzuki T, Itohara S. Unaltered secretion of $\beta$-amyloid precursor protein in gelatinase A (matrix metalloproteinase 2)-deficient mice. J Biol Chem 1997; 272: 22389-92.

31. Itoh T, Tanioka M, Yoshida H, Yoshioka T, Nishimoto H, Itohara S. Reduced angiogenesis and tumor progression in gelatinase A-deficient mice. Cancer Res 1998; 58: 1048-51.

32. Digirolamo M, Fine JB, Tagra K, Rossmanith R. Qualitative regional differences in adipose tissue growth and cellularity in male Wistar rats fed ad libitum. Am J Physiol 1998; 274: R1460-7.

33. Spiegelman BM, Flier JS. Adipogenesis and obesity: rounding out the big picture. Cell 1996; 87: 377-89.

34. Geloen A, Roy PE, Bukowecki LJ. Regression of white adipose tissue in diabetic rats. Am J Physiol 1989; 257: E547-E53.

Received July 11, 2000 Accepted after resubmission January 16, 2001 